\title{
EVALUACIÓN DE LA MORFOMETRÍA DE PELLETS COMO MÉTODO DE CATEGORIZACIÓN DE SEXOS Y EDADES EN VENADO COLA BLANCA (Odocoileus virginianus mexicanus) EN PUEBLA, MÉXICO
}

\author{
ANGELA A. CAMARGO-SANABRIA ${ }^{1}$ Y SALVADOR MANDUJANO² $^{2}$ \\ ${ }^{1}$ División de Posgrado, Instituto de Ecología, A. C. km. 2.5 Carretera Antigua a Coatepec \\ No. 351, Congregación del Haya, Xalapa 91070, Veracruz, México \\ ${ }^{2}$ Red de Biodiversidad y Ecología Animal, Instituto de Ecología, A. C. km. 2.5 Carretera \\ Antigua a Coatepec No. 351, Congregación del Haya, Xalapa 91070, Veracruz, México, \\ correo electrónico: angela.andrea.camargo@gmail.com
}

Resumen: Tanto desde una perspectiva ecológica como de manejo, es importante conocer la proporción de sexos y la estructura de edades de las poblaciones de venado cola blanca (Odocoileus virginianus). Sin embargo, en aquellos lugares donde no es posible ver directamente a los animales en vida libre, no es sencillo determinar su edad y sexo por lo que se han empleado métodos indirectos como el análisis morfométrico de los pellets. Con el fin de determinar si la variación entre pellets de individuos de diferentes edades y sexo permite su correcta categorización, se colectaron los grupos fecales de individuos conocidos en cautiverio en la UMA-Zoológico Flor del Bosque, Puebla. Se obtuvieron 180 muestras de las cuales 18 fueron de crías ( $<1$ año), 78 de juveniles ( $2-3$ años) y 84 de adultos ( $>3$ años). Se comparó el promedio de todas las variables morfométricas entre grupos fecales de un mismo individuo y entre individuos de la misma clase de edad y sexo. Nuestros resultados sugieren que dada la alta variación presentada en las medidas morfométricas de los pellets de un mismo individuo en una misma época y entre épocas del año, y la baja variación mostrada entre grupos fecales de individuos de diferentes clases de edad y sexo, el análisis morfométrico de pellets es una metodología poco confiable para determinar la estructura de edad y sexo de una población de $O$. v. mexicanus. En consecuencia, la técnica de clasificación fuzzy no logra una categorización adecuada de la población en estudio pues sólo separa a los machos adultos de 5 y 6 años, mientras que los machos de menor edad y juveniles, así como hembras adultas y juveniles no son discriminados en clases separadas. Se sugiere realizar análisis similares a este con otras subespecies de venado que no exhiban un fuerte dimorfismo sexual como aquellas distribuidas hacia el centro y sur de México.

Palabras clave: estructura de edades, método indirecto, pellets, técnica fuzzy, Odocoileus virginianus.

Abstract: Both from an ecological perspective as management, it is important to know the sex
ratio and age structure of populations of white-tailed deer (Odocoileus virginianus). However,
in places where you can not directly see the animals in the wild is not easy to determine their 
age and sex so indirect methods have been used as a morphometric analysis of the pellets. To determine whether the variation between pellets of individuals of different age and sex allows proper categorization, fecal groups were collected from known individuals in captivity in the Zoo UMA-Flor del Bosque, Puebla. We obtained 180 samples of which 18 were young $(<1$ year), 78 juveniles (2-3 years) and 84 adults ( $>3$ years). We compared the average for all morphometric variables between groups fecal same individual and between individuals of the same age class and sex. Our results suggest that given the high variation shown in the body measures of the pellets from the same individual in the same season and between seasons, and low fecal variation shown between groups of individuals of different age classes and sex, analysis morphometry of pellets is an unreliable method to determine the age and sex structure of a population of $O$. v. mexicanus. Consequently, the fuzzy classification technique does not achieve appropriate categorization of the study population because only separates adult males of 5 and 6 years, while younger males and juveniles and adult females and juveniles are not discriminated against in separate classes. Similar analysis suggested this to other subspecies of deer that do not exhibit strong sexual dimorphism as those distributed to the central and southern Mexico.

Key words: Structure of ages, indirect method, pellets, technology fuzzy, Odocoileus virginianus.

\section{INTRODUCCIÓN}

El éxito del manejo de poblaciones silvestres de fauna depende del conocimiento de la estructura y de su dinámica poblacional (Ojasti, 2000). La dinámica de cualquier población es función de la variación en el tiempo y en el espacio en tasas vitales como la de natalidad y sobrevivencia lo que determina el crecimiento poblacional. Esto define la densidad poblacional, la estructura de edades, y la proporción de sexos. De éstos, el tamaño poblacional es quizá el aspecto más importante pues la finalidad y éxito de las acciones de manejo son frecuentemente expresadas en términos de este número (Lancia et al., 1996). En los ungulados las tasas de sobrevivencia y mortalidad varían según las clases de sexo y edad (Clutton-Brock y Lonergan, 1994; Coulson et al., 2001), por lo tanto, el conocimiento de la estructura poblacional juega un papel fundamental en su manejo. Para el venado cola blanca, la especie de fauna silvestre más importante desde el punto de vista económico y cinegético en México, el conocimiento de la proporción de sexos y estructura de edades de sus poblaciones resulta tan importante como el de su densidad (Villarreal, 1996).

Dado el frecuente conteo de grupos fecales como método de estimación de la densidad poblacional, es deseable que sirva para obtener estimaciones adecuadas de la estructura poblacional (MacCracken y van Ballenberghe, 1987; Sánchez-Rojas et al., 2004). Así el análisis morfométrico de pellets ha evidenciado una relación entre el sexo y edad de los individuos y la morfología del pellet, demostrando su utilidad en ungulados como el venado cola blanca de Coues (Odocoileus virginianus conesi; 
Ezcurra y Gallina, 1981), el alce (Alces alces; MacCracken y van Ballenberghe, 1987) y el venado bura (O. hemionus; Sánchez-Rojas et al., 2004). Sin embargo, MacCracken y van Ballenberghe (1987) sugieren que la técnica de morfometría de pellets no sería útil en especies que no exhiben un fuerte dimorfismo sexual y en poblaciones donde los machos grandes son fuertemente cazados.

El creciente interés en el aprovechamiento cinegético del venado cola blanca en el centro y sur del país, evidencia la necesidad de contar con métodos de estimación de la densidad y estructura poblacional que puedan ser utilizados en lugares con bajos niveles poblacionales de venado y donde se dificulta el uso de métodos directos. En el presente estudio se evaluó el análisis morfométrico de pellets como método de categorización de clases de edad y sexo en venado cola blanca de la subespecie $O$. v. mexicanus en Puebla.

\section{MÉTODOS}

\section{Área de estudio}

La colecta de los grupos fecales se hizo en el parque General Lázaro Cárdenas del Río "Flor del Bosque" perteneciente a la Secretaría de Desarrollo Urbano y Ecología del Estado de Puebla, al suroeste del municipio de Amozoc. El parque cuenta con una superficie de 614 ha, su temperatura media anual es de $18{ }^{\circ} \mathrm{C}$ y posee una altitud que va de los 2200 hasta los 2470 msnm (Romero y Martínez-Romero, 1998). El parque incluye una UMA-Zoológico que para 2006 contaba con 35 venados cola blanca $O$. $v$. mexicanus en un cercado de 4 ha rodeado de malla ciclónica de $4 \mathrm{~m}$ de altura. El área cercada se caracterizó por vegetación secundaria, pastizales y eucaliptos (Romero y Martínez-Romero, 1998). La población de venados en cautiverio estaba conformada por 12 machos adultos (34\%), 15 hembras adultas (43\%) y 8 individuos de las clases juvenil y crías (23\%; L. E. Martínez-Romero, com. pers.).

\section{Fase de campo}

En abril de 2006 colectamos los grupos fecales de algunos individuos de edad y sexo conocido. En este muestreo identificamos ocho animales que fueron utilizados como focales para seguir muestreándolos en los meses de agosto y diciembre del mismo año. Las muestras fueron procesadas y a cada grupo fecal se le tomaron fotos separando cada pellet. Este procedimiento permitió tener medidas del $100 \%$ de los pellets que conforman un grupo fecal. Esto difiere del procedimiento previamente empleado en otros estudios (e.g., Ezcurra y Gallina, 1981) donde solo se miden algunos pellets "característicos" del grupo fecal. Todas las fotos de los grupos fecales fueron analizadas con el programa de cómputo Image J (Rasband, 1997), para obtener las 
medidas de área, longitud (L) y ancho (A) de cada pellet. A partir de las medidas de longitud y ancho, calculamos el volumen (V) y la proporción L/A. Se colectaron 189 grupos fecales pertenecientes a todas las clases de sexo y edad. Considerando la clasificación en tres categorías de edad, 60 grupos fecales (32\%) fueron de juveniles, $74(39 \%)$ de hembras adultas y 55 (29\%) de machos adultos.

\section{Análisis de datos}

Obtuvimos las estadísticas descriptivas de las cinco variables morfométricas en el programa de cómputo R (R Development Core Team, 2006). Para comparar entre clases de edad y sexo aplicamos un análisis multivariado de varianza (MANOVA). Posteriormente, aplicamos análisis de varianza (ANOVA) a cada variable y una prueba de Tukey. Agrupamos los individuos en categorías de edad: crías y juveniles de 0 a 2 años de edad; hembras adultas de 2 a 5 años de edad; y, machos adultos de 2 a 6 años y realizamos un ANOVA por cada variable morfométrica. Analizamos la variación en las medidas morfométricas de los grupos fecales de animales focales, comparando el promedio de cada variable para todos los individuos focales entre periodos de muestreo con un modelo de efectos mixtos. Realizamos ANOVAs anidados para determinar si existen diferencias significativas en las medidas de los grupos fecales de un individuo dentro de épocas.

\section{Evaluación del desempeño de la técnica de clasificación de conjuntos difusos}

Utilizamos el programa de cómputo Fuzzy clustering tool (Equihua-Zamora, 2001) para categorizar los grupos fecales colectados en el primer muestreo y así, probar la exactitud de la técnica $k$-medias difusa, en adelante referida como "fuzzy" para asignar individuos a clases de edad y sexo conocida. Teniendo en cuenta la categorización de la población por sexos y edades, definimos tres conjuntos fuzzy: I: juveniles, II: hembras adultas, III: machos adultos. Realizamos tres ensayos de categorización: 1) usando todas las medidas morfométricas, 2) usando cada medida morfométrica por separado y 3) quitando los datos de machos adultos de 5 y 6 años. Este último ensayo se hizo considerando que los datos de machos de estas edades fueron separados en conjuntos aparte en los ensayos 1 y 2 . Asignamos cada grupo fecal a uno de los tres conjuntos con base en la mayor membresía. Con los datos del primer muestreo de los animales focales, graficamos por cada animal el número de grupos que eran clasificados en cada conjunto; esperamos que todos los grupos fecales de un individuo sean asignados a un solo conjunto. 


\section{RESULTADOS}

\section{Comparación entre grupos fecales de individuos de distintas clases de edad y sexo}

El MANOVA indicó que existe un efecto altamente significativo de los factores sexo (Wilks $=0.8, \mathrm{gl}=1, p<0.001)$, edad (Wilks $=0.3, \mathrm{gl}=5, p<0.001)$ y su interacción (Wilks $=0.7, \mathrm{gl}=4, p<0.001$ ) sobre las medidas morfométricas. Se encontraron diferencias significativas al comparar el área, el eje mayor, el eje menor y el volumen entre sexos, entre edades y en la interacción sexo:edad. La proporción L/A varió significativamente entre edades y en la interacción sexo:edad, pero no entre sexos (Cuadro 1). Los machos de 5 y 6 años siempre tuvieron los mayores valores promedio de las variables morfométricas, excepto para la proporción L/A. Las edades 1, 2, 3 y 4 de los machos y todas las edades de las hembras tuvieron promedios similares para todas las variables (Figura 1).

Al agrupar las edades en categorías (juveniles, hembras adultas y machos adultos), no se encontraron diferencias significativas entre ellas en la variable proporción L $/ \mathrm{A}$ (ANOVA, $F=0.24, \mathrm{gl}=2 \mathrm{y} 178, p=0.78$ ) pero sí en el área (ANOVA, $F$ $=33.3, \mathrm{gl}=2$ y $178, p<0.05)$, eje mayor (ANOVA, $F=18.8, \mathrm{gl}=2$ y $178, p<0.05$ ), eje menor (ANOVA, $F=23.4, \mathrm{gl}=2$ y $178, p<0.05$ ) y volumen (ANOVA, $F=35.3, \mathrm{gl}=2 \mathrm{y}$ $178, p<0.05)$.

Cuadro 1. Prueba de ANOVA para la comparación de las medidas morfométricas entre sexos $($ g.l. $=1,169)$, edades (g.l. = 5, 169) y la interacción sexo:edad $($ g.l. = 4, 169).

\begin{tabular}{llll}
\hline Variable & Entre sexos & Entre edades & Sexo:Edad \\
\hline Área & $F=23.4, p<0.05$ & $F=13.8, p<0.05$ & $F=4.4, p<0.05$ \\
Eje mayor & $F=19.3, p<0.05$ & $F=9.1, p<0.05$ & $F=6.0, p<0.05$ \\
Eje menor & $F=23.0, p<0.05$ & $F=17.8, p<0.05$ & $F=3.5, p<0.05$ \\
Proporción L/A & $F=0.006, p=0.93$ & $F=4.9, p<0.05$ & $F=3.8, p<0.05$ \\
Volumen & $F=22.5, p<0.05$ & $F=16.1, p<0.05$ & $F=4.4, p<0.05$ \\
\hline
\end{tabular}



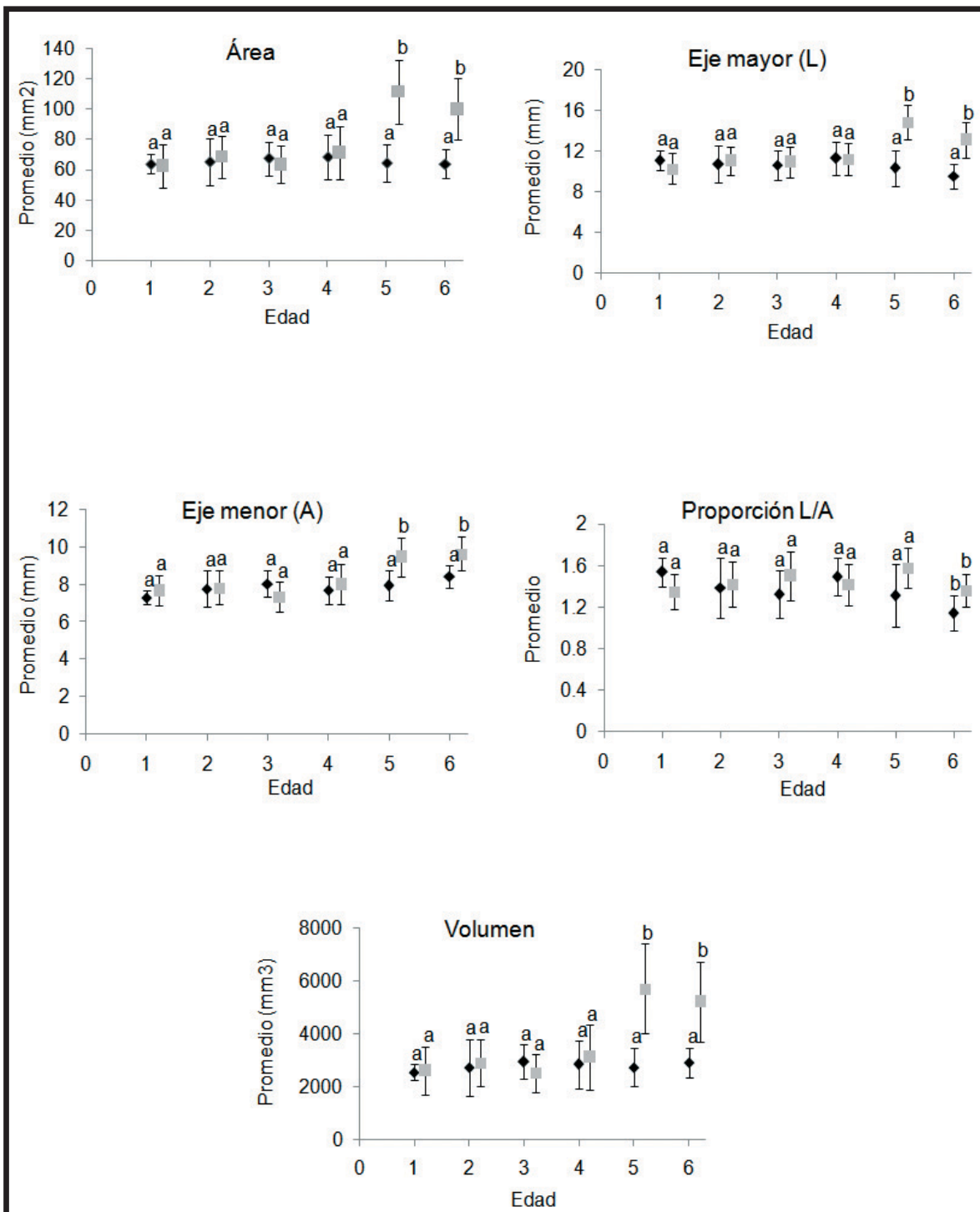

Figura 1. Valores promedio y desviación estándar para cada una de las medidas morfométricas, según sexo y edad, $\mathrm{n}=189$. Las letras indican la significancia del ANOVA, "aa" o "bb" = diferencias no significativas, combinación "ab" = diferencias significativas $(\mathrm{p}<0.05)$. Machos $(\square)$; Hembras $(\bullet)$. 


\section{Variación morfométrica entre grupos fecales de un mismo individuo dentro y entre épocas}

La comparación de las medidas morfométricas con el modelo de efectos mixtos mostró que existen diferencias significativas entre sexos y que el mayor porcentaje de la variación de los datos está explicado por las diferencias entre épocas. En la Figura 2 se presenta un ejemplo para la variable morfométrica eje mayor. Todas las variables, excepto la proporción L/A, presentaron los valores más altos en el periodo 2 que corresponde con la época de lluvias.

La comparación de las medidas morfométricas de los pellets dentro de cada época mostró que para seis de los ocho animales focales, los grupos fecales difirieron significativamente dentro de épocas en al menos una variable morfométrica. La proporción L/A y el eje mayor fueron las medidas morfométricas menos variables dentro de épocas para seis y cinco de los ocho animales focales, respectivamente. En la Figura 3 se presenta un ejemplo para un macho de 6 años que muestra la gran variabilidad que existe en las medidas de los pellets dentro y entre grupos fecales de un mismo periodo y entre grupos de diferentes periodos para un mismo individuo. Este mismo patrón se observó para todos los animales muestreados.

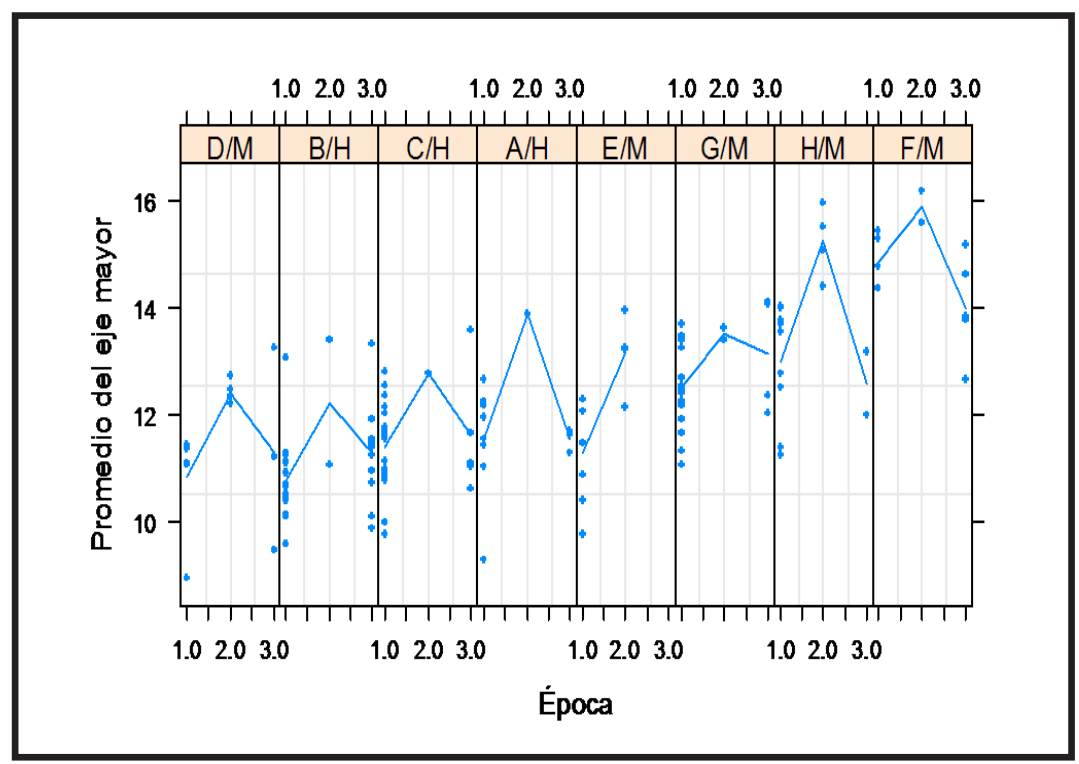

Figura 2. Variación en el eje mayor entre épocas dada la identidad de cada individuo focal. En el recuadro superior rosado la primera letra indica la identidad del animal, la segunda letra indica el sexo $(\mathrm{H}=$ Hembra, $\mathrm{M}=$ Macho). Los números en los bordes externos indican el periodo de muestreo. 


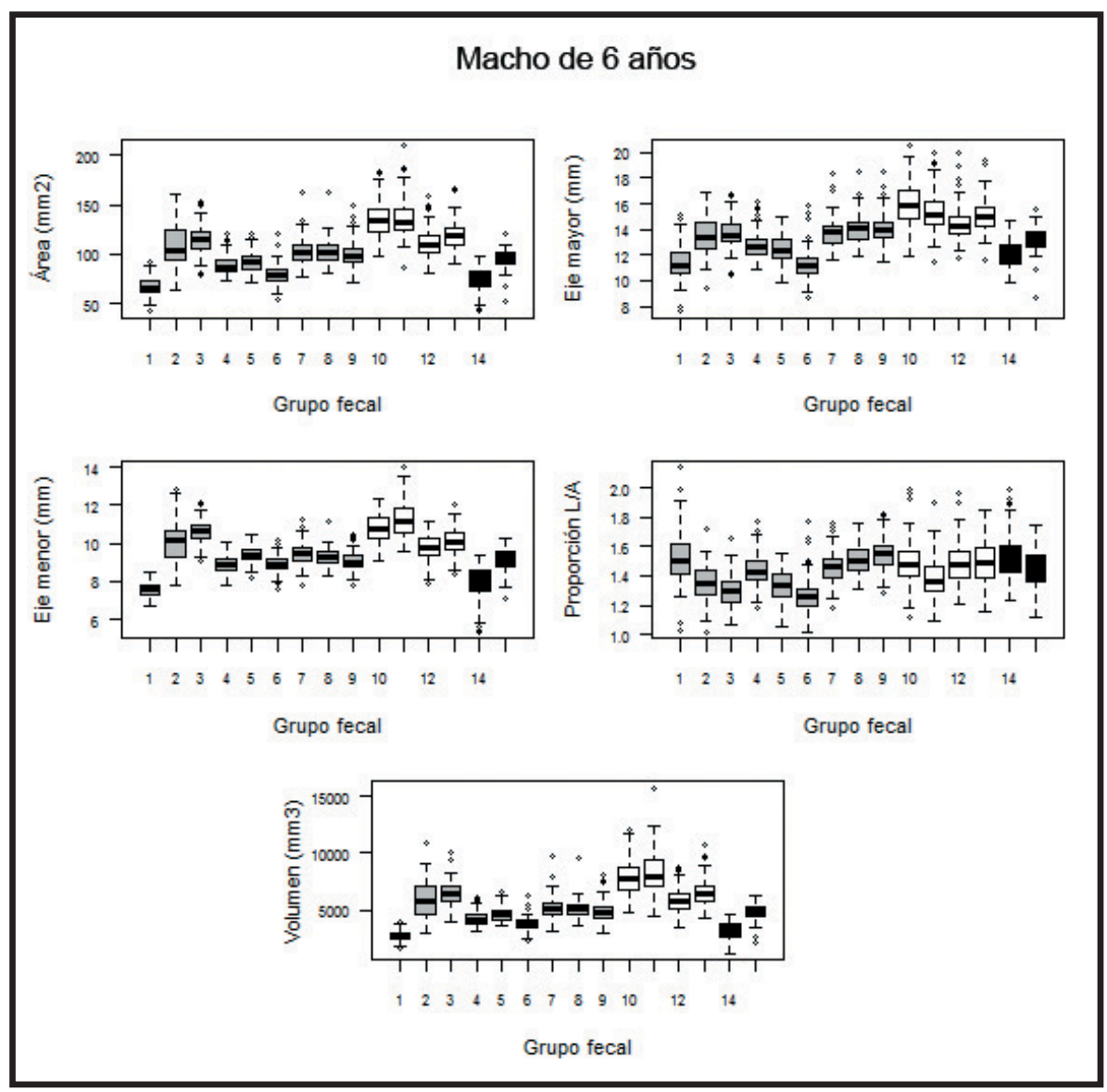

Figura 3. Ejemplo de la variación en las medidas morfométricas de los pellets durante los tres periodos de muestreo para un mismo individuo. Este ejemplo es ilustrativo de lo que se encontró en todos los individuos analizados.

\section{Evaluación del desempeño de la técnica de clasificación fuzzy}

Primer ensayo.-Usando todas las medidas morfométricas, la técnica fuzzy colocó al 56\% de las muestras en el conjunto I, el 32\% en el conjunto II y el 12\% en el conjunto III (Cuadro 2). El conjunto I presentó los valores más bajos en todas las 
variables, excepto en la proporción L/A, seguido por el conjunto II y finalmente el conjunto III. Con este análisis, en el conjunto I quedaron incluidos individuos de todas las edades, excepto los machos de 5 años, en el conjunto II todas las edades, excepto crías, hembras de 1 año y machos de 5 años, y en el conjunto III los machos adultos de 5 y 6 años.

Segundo ensayo.-Al utilizar cada una de las medidas morfométricas, se encontró que tanto la asignación a cada conjunto como el porcentaje de grupos fecales pertenecientes a cada uno varía (Cuadro 2). La clasificación obtenida utilizando solamente el volumen produjo los mismos resultados que la proporcionada por todas las variables.

Tercer ensayo.- - Sin los datos de machos de 5 años, nuevamente en los conjuntos I y II quedan clasificados individuos de todas las edades y en el conjunto III los machos de 6 años (Cuadro 2). Sin los datos de machos de 5 y 6 años, la clasificación es poco discriminatoria, individuos de todas las edades quedan asignados a los tres conjuntos, a excepción del dato de la cría que no es incluida en los conjuntos II ni III y machos de 1 año que no son incluidos en el conjunto II.

Asignación de los grupos fecales de individuos focales a los conjuntos de fuzzy.-Los grupos fecales de todos los individuos, excepto los del macho de 2 años, son asignados a más de un conjunto (Figura 4). Los grupos fecales de hembras y machos de 1 a 4 años son clasificados en los conjuntos I y II, mientras que los de los machos adultos son asignados a los conjuntos II y III preferentemente.

Cuadro 2. Comparación de las estructuras poblacionales (\%) generadas en cada ensayo con la estructura real del grupo en cautiverio.

\begin{tabular}{|c|c|c|c|c|c|c|c|c|}
\hline \multirow[b]{2}{*}{$\begin{array}{l}\text { Categoría } \\
\text { de edad }\end{array}$} & \multirow[b]{2}{*}{$\begin{array}{c}\text { Estructura } \\
\text { real }\end{array}$} & \multirow[t]{2}{*}{ Ensayo 1} & \multicolumn{3}{|c|}{ Ensayo 2} & \multicolumn{3}{|c|}{ Ensayo 3} \\
\hline & & & Área & $\begin{array}{l}\text { Eje } \\
\text { mayor }\end{array}$ & $\begin{array}{c}\text { Eje } \\
\text { menor }\end{array}$ & Volumen & Sin M5 & $\begin{array}{c}\text { Sin M5 y } \\
\text { M6 }\end{array}$ \\
\hline $\mathrm{J}$ & 23 & 56 & 50 & 32 & 39 & 56 & 58 & 42 \\
\hline $\mathrm{H}$ & 43 & 32 & 37 & 52 & 47 & 32 & 32 & 40 \\
\hline M & 34 & 12 & 13 & 16 & 14 & 12 & 10 & 18 \\
\hline
\end{tabular}

J: Juveniles, H: Hembras adultas, M: Machos adultos 


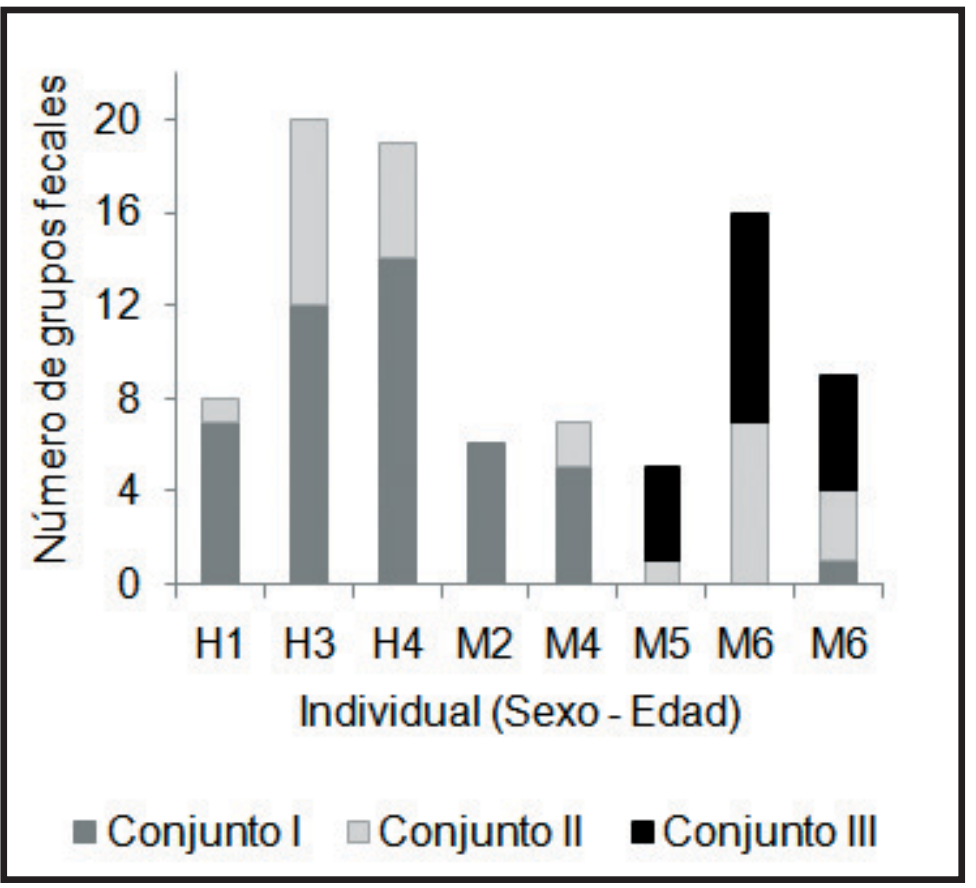

Figura 4. Número de grupos fecales de animales focales asignado a cada conjunto (I: juveniles, II: hembras adultas, III: machos adultos).

\section{DISCUSIÓN}

Nuestros resultados sugieren que dada la alta variación presentada en las medidas morfométricas de los pellets de un mismo individuo en una misma época y entre épocas del año, y la baja variación mostrada entre grupos fecales de individuos de diferentes clases de edad y sexo, el análisis morfométrico de pellets es una metodología poco confiable para determinar la estructura de edad y sexo de una población de $O$. virginianus mexicanus. En consecuencia, la técnica de clasificación fuzzy no logra una categorización adecuada de la población en estudio pues sólo separa a los machos de 5 y 6 años.

Este estudio evidenció que las medidas morfométricas de los pellets de los grupos fecales de un mismo individuo varían de manera significativa dentro y entre épocas. La variación entre épocas en donde los pellets de la época de lluvias son más 
grandes que los de los otros periodos podría relacionarse con cambios en la dieta. La variación individual dentro y entre épocas como resultado del aumento en la ingesta de comida, se ha demostrado en el número de grupos fecales depositados por animal por día y en el peso de los grupos fecales y de los pellets (Arthur y Alldredge, 1980; McCullough, 1982; Rogers, 1987). Para determinar el efecto de la dieta sugerimos conducir un estudio experimental en el que se controle el tipo y cantidad de alimentos consumidos por los animales y se tomen las medidas morfométricas de pellets de grupos fecales colectados durante días sucesivos.

El análisis morfométrico de pellets para esta subespecie de venado no evidenció diferencias significativas entre animales de sexos y edades diferentes; sólo los grupos fecales de los machos más grandes tuvieron promedios significativamente diferentes. El método morfométrico se basa en el supuesto que el tamaño del cuerpo es un indicador de la edad del animal y que las medidas de los pellets dependen del tamaño corporal (Bubenik, 1982 citado en MacCracken y van Ballenberghe, 1987). Sin embargo, aún cuando el dimorfismo sexual ocurra, las medidas de machos y hembras usualmente se sobrelapan (Kunz et al., 1996); por tanto, es de esperarse que si el tamaño del cuerpo influye el tamaño del pellet y el primero es un criterio fiable solamente en los extremos, los pellets que pueden separarse son los de los animales más pequeños y más grandes, esto último como en el presente estudio.

En nuestro estudio, la falta de poder discriminatorio del método de clasificación podría deberse al pequeño dimorfismo sexual que existe en la subespecie del venado cola blanca mexicano en comparación con el venado cola blanca de Coues o el venado bura. Según MacCracken y van Ballenberghe (1987) el análisis morfométrico de pellets puede no ser útil cuando se presenta esta situación. Sugerimos evaluar el análisis morfométrico de pellets para asignar individuos a categorías de sexo y edad en otras subespecies pequeñas de venado. Si se encuentra que sólo se separa a los machos más grandes de la población, se podría concluir que este método sólo funciona para subespecies grandes.

La técnica de clasificación fuzzy no permitió categorizar de manera adecuada el grupo de venados en estudio, a diferencia de lo registrado por Sánchez-Rojas et al., (2004) para el venado bura. La variación individual dentro y entre épocas en las medidas morfométricas de los pellets pudo producir esta baja exactitud pues excepto tres animales focales (hembra de 1 año, macho de 2 años y macho de 5 años), los grupos fecales de los restantes individuos no fueron asignados correctamente a un solo conjunto de fuzzy. Esto se traduce en que dependiendo de los pellets o el grupo fecal medido, un animal puede quedar clasificado como juvenil en unas ocasiones y como hembra en otras.

Para aplicar tasas de cosecha correctas se debe contar con estimaciones exactas de la estructura poblacional; si el análisis morfométrico de pellets no proporciona esta información se hace necesario explorar otras herramientas 
metodológicas que también usan las heces. Dentro de las que se han usado con ungulados están el uso de DNA (Huber et al., 2002; Lindsay y Belant, 2007) o la proporción entre las hormonas estradiol/testosterona (Martínez-Romero, 2004).

\section{AGRADECIMIENTOS}

Agradecemos a L. E. Martínez y D. Pérez por la ayuda en el muestreo de los venados en cautiverio y por las facilidades prestadas por la UMA-Zoológico Flor del Bosque. Además, agradecemos a R. Guevara, E. Naranjo, G. Sánchez-Rojas y J. Pérez-Torres por sus comentarios a la versión inicial del manuscrito. Fondos para el proyecto fueron proporcionados por el CONACYT y la Red de Biología y Conservación de Vertebrados, Instituto de Ecología A. C.

\section{LITERATURACITADA}

Arthur, W.J. y A.W. Alldredge. 1980. Seasonal estimates of masses of mule deer fecal pellets and pellets groups. Journal of Wildlife Management, 44:750-752.

Clutton-Brock, T.H. y M.E. Lonergan. 1994. Culling regimes and sex ratio biases in highland red deer. Journal of Applied Ecology, 31:521-527.

Coulson, T., E.A. Catchpole, S.D. Albon, B.J.T. Morgan, J.M. Pemberton, T.H. CluttonBrock, M.J. Crawley y B.T. Grenfell. 2001. Age, sex, density, winter weather, and population crashes in Soay sheep. Science, 292:1528-1531.

Equihua-Zamora, M. 2001. Fuzzy clustering tool. Versión 2.0. Instituto de Ecología, A.C.

Ezcurra, E. y S. Gallina. 1981. Biology and population dynamics of white-tailed deer in northwestern Mexico. Pp. 77-108, en: Deer biology, habitat requirements, and management in western North America (P.F. Ffolliot y S. Gallina, eds.). Instituto de Ecología, A. C. México.

Huber, S.U. Bruns y W. Arnold. 2002. Sex determination of red deer using polymerase chain reaction of DNA from feces. Wildlife Society Bulletin, 30:208-212.

Kunz, T.H., C. Wemmer y V. Hayssen. 1996. Appendix 5: Sex, age, and reproductive condition of mammals. Pp. 279-290, en: Measuring and monitoring biological diversity, Standard methods for mammals (D.E. Wilson, F. Russell-Cole, J.D. Nichols, R, Rudran y M.S. Foster, eds.). Smithsonian Institution. USA.

Lancia, R.A., J.D. Nichols y K.H. Pollock. 1996. Estimating the number of animals in wildlife populations. Pp. 215-253, en: Research and Management Techniques for Wildlife and Habitats (T.A. Bookhout, ed.). Fifth edition. The Wildlife Society. Bethesda, MD., USA.

Lindsay, A.R. y J.L. Belant. 2007. A simple and improved PCR-based technique for whitetailed deer (Odocoileus virginianus) sex identification. Conservation Genetics, DOI 10.1007/s10592-007-9326-y.

MacCracken, J.G. y van Ballenberghe. 1987. Age-and sex-related differences in fecal pellet dimensions of moose. Journal of Wildlife Management, 51:360-364. 
Martínez-Romero, L.E. 2004. Determinación de fechas de aprovechamiento del venado cola blanca (Odocoileus virginianus) a través de hormonas sexuales y comportamiento. Tesis de Maestría. Instituto de Ecología, A.C. Xalapa, México.

McCullough, D.R. 1982. White-tailed deer pellet-groups weights. Journal of Wildlife Management, 46: 829-832.

Ojasti, J. 2000. Manejo de fauna silvestre neotropical. F. Dallmeier, editor. SIMAB Series No. 5. Smithsonian Institution/MAB Program, Washington, D.C.

R Development Core Team. 2006. R: A language and environment for statistical computing. R Foundation for Statistical Computing, Vienna, Austria. ISBN 3-900051-07-0, URL http:/ /www.R-project.org.

Rasband, W.S. 1997-2007. ImageJ, U. S. National Institutes of Health, Bethesda, Maryland, USA, http://rsb.info.nih.gov/ij/. Java 1.5.0_09

Rogers, L.L. 1987. Seasonal changes in defecation rates of free-ranging white-tailed deer. Journal of Wildlife Management, 51:330-333.

Romero, S. y. L.E. Martínez-Romero. 1998. Programa de rescate del venado cola blanca (Odocoileus virginianus) en el parque estatal General Lázaro Cárdenas del Río "Flor del Bosque", en Puebla. Memorias VI simposio de venados en México, UNAM, Xalapa, Ver.

Sánchez-Rojas, G., S. Gallina y M. Equihua. 2004. Pellet morphometry as a tool to distinguish age and sex in the mule deer. Zoo-Biology, 23:139-146.

Villarreal, J. 1996. Importancia de la relación machos:hembras en la producción de trofeos de venado cola blanca (Odocoileus virginianus). Memorias V Simposio de venados en México. UNAM, Quintana Roo. 